\title{
How Return and Risk Experiences Shape Investor Beliefs and Preferences
}

Citation for published version (APA):

Hoffmann, A., \& Post, T. (2017). How Return and Risk Experiences Shape Investor Beliefs and

Preferences. Accounting and Finance, 57(3), 759-788. https://doi.org/10.1111/acfi.12169

Document status and date:

Published: 01/09/2017

DOI:

10.1111/acfi.12169

Document Version:

Accepted author manuscript (Peer reviewed / editorial board version)

\section{Please check the document version of this publication:}

- A submitted manuscript is the version of the article upon submission and before peer-review. There can be important differences between the submitted version and the official published version of record.

People interested in the research are advised to contact the author for the final version of the publication, or visit the DOI to the publisher's website.

- The final author version and the galley proof are versions of the publication after peer review.

- The final published version features the final layout of the paper including the volume, issue and page numbers.

Link to publication

\footnotetext{
General rights rights.

- You may freely distribute the URL identifying the publication in the public portal. please follow below link for the End User Agreement:

www.umlib.nl/taverne-license

Take down policy

If you believe that this document breaches copyright please contact us at:

repository@maastrichtuniversity.nl

providing details and we will investigate your claim.
}

Copyright and moral rights for the publications made accessible in the public portal are retained by the authors and/or other copyright owners and it is a condition of accessing publications that users recognise and abide by the legal requirements associated with these

- Users may download and print one copy of any publication from the public portal for the purpose of private study or research.

- You may not further distribute the material or use it for any profit-making activity or commercial gain

If the publication is distributed under the terms of Article $25 \mathrm{fa}$ of the Dutch Copyright Act, indicated by the "Taverne" license above, 


\title{
How Return and Risk Experiences Shape Investor Beliefs and Preferences
}

\author{
Arvid O. I. Hoffmann* \\ Maastricht University and Netspar \\ Thomas Post \\ Maastricht University and Netspar
}

This version: August 17, 2015

\begin{abstract}
Combining brokerage records and matching monthly survey measurements of a sample of individual investors from the Netherlands for the period April 2008 through March 2009, we examine how individual investors update their beliefs (return expectations and risk perceptions) and preferences (risk tolerance) as a result of their personal return and risk experiences. Past returns positively impact return expectations and risk tolerance, and negatively impact risk perceptions. Realized risk, however, has no effect. That is, even in a highly volatile stockmarket period in which risk appears very salient, investors do not take it into account when updating their beliefs and preferences.
\end{abstract}

JEL Classification: D14, D81, D83, D84, G02, G11

Keywords: Behavioral Finance, Household Finance, Individual Investors, Return Experiences, Risk Experiences, Investor Beliefs, Investor Preferences

* Corresponding author: Arvid O. I. Hoffmann, Maastricht University, School of Business and Economics, Department of Finance, P.O. Box 616, 6200 MD, The Netherlands. Tel.: +31 433884 602. E-mail: a.hoffmann@maastrichtuniversity.nl.

This research would not have been possible without the help of a large brokerage firm. The authors thank this broker for making available its data and its employees for answering numerous questions. The authors thank the editor, Tom Smith, the deputy editor, Gary Monroe, and two anonymous reviewers for their constructive guidance through the review process. For their comments on earlier drafts of this paper and helpful discussions, the authors thank Brad Barber, Jaap Bos, Jingjing Chai, John Chalmers, Prachi Deuskar, Simon Gervais, David Hirshleifer, Cars Hommes, Matti Keloharju, Marc Kramer, Christoph Merkle, Elias Rantapuska, Paul Smeets, Stefan Straetmans, Richard Taffler, Cesira Urzi, Mei Wang, and seminar and conference participants at the University of New South Wales, Maastricht University, the University of Amsterdam, the University of Münster, the Goethe-University Frankfurt, the Colloquium on Financial Markets at the Centre for Financial Research, the ZEW conference on The Role of Expectations in Financial Markets, the Netspar International Pension Workshop, the Boulder Summer Conference on Consumer Financial Decision Making, the Annual Meeting of the German Finance Association, the Annual Meeting of the Financial Management Association, the University of Sterling, the European Retail Investment Conference, the European Conference of the Financial Management Association, the Individual Finance and Insurance Decisions Centre, the Tilburg Institute for Behavioral Economics Research (TIBER) Symposium on Psychology and Economics, and the NIBS Workshop on Household Financial Decision Making and Behaviour in Financial Markets. Earlier versions of this paper circulated under the title "What Makes Investors Optimistic, What Makes Them Afraid?" The authors thank Donna Maurer for her editorial assistance. Any remaining errors are those of the authors. 


\title{
How Return and Risk Experiences Shape Investor Beliefs and Preferences
}

\author{
Accounting and Finance, Forthcoming
}

\begin{abstract}
Combining brokerage records and matching monthly survey measurements of a sample of individual investors from the Netherlands for the period April 2008 through March 2009, we examine how individual investors update their beliefs (return expectations and risk perceptions) and preferences (risk tolerance) as a result of their personal return and risk experiences. Past returns positively impact return expectations and risk tolerance, and negatively impact risk perceptions. Realized risk, however, has no effect. That is, even in a highly volatile stockmarket period in which risk appears very salient, investors do not take it into account when updating their beliefs and preferences.
\end{abstract}




\section{Introduction}

There is an increasing interest in how behavioral factors affect financial markets (Bowman and Buchanan, 1995; Blasco, Corredor, and Ferreruela, 2012; Shu et al., 2013). The majority of such research is from a corporate, investment, or market perspective (Benson, Faff, and Smith, 2014). Moreover, there is a relative scarcity of research employing alternative methodologies to quantitative, such as surveys and experiments (Benson et al., 2015). Noteworthy exceptions are recent studies on the behavioral underpinnings of individual investor beliefs and preferences (Tourani-Rad and Kirkby, 2005; Harding and He, 2015; Gerrans, Faff, and Hartnett, 2015). We add to this emerging stream of literature by conducting a field study to examine how individual investors update their beliefs (i.e., return expectations and risk perceptions) and preferences (i.e., risk tolerance) in response to personal return and risk experiences. We analyze a unique combination of Dutch brokerage records and matching monthly survey measurements of return expectations, risk perceptions, and risk tolerance. It is important to understand how individual investors update their beliefs and preferences, because these are central determinants of their trading and risk-taking behavior (Hoffmann, Post, and Pennings, 2015). Individual investor behavior, in turn, can affect asset prices (Hirshleifer, 2001; Kumar and Lee, 2006; Kogan et al., 2006; Barber, Odean, and Zhu, 2009; Han and Kumar, 2013), return volatility (Foucault, Sraer, and Thesmar, 2011), and the macro-economy (Korniotis and Kumar, 2011a).

Our sample period from April 2008 through March 2009 corresponds to a time of considerable stock-market volatility. Accordingly, there is substantial variation in investors' beliefs and preferences, as well as in their portfolio returns and risk, which is beneficial for examining the effect of investors' realized portfolio returns and risk on subsequent changes in their beliefs and preferences. We find that investors' past returns positively impact their return 
expectations and risk tolerance, and negatively impact their risk perceptions. Thus, when updating beliefs and preferences, investors extrapolate recent return experiences. The risk of these past returns (as measured by their standard deviation), however, does not impact investors' return expectations, risk perceptions, or risk tolerance. Thus, even in a highly volatile stockmarket period in which risk appears very salient, investors do not take it into account when updating their beliefs and preferences. The absence of an effect of risk relates to the complexity of standard risk measures, investor sophistication, and potentially the lower availability of risk signals. We do not find evidence that the updating process of investor beliefs and preferences is compatible with a rational benchmark. Rather, return and risk experiences influence beliefs and preferences consistent with behavioral finance predictions.

This paper builds upon earlier experimental work and extends scant field evidence on how return and risk experiences drive updates in individual investor beliefs and preferences. Prior experimental literature indicates that both return and risk experiences are important in shaping investors' beliefs and preferences. This literature, however, draws on various behavioral concepts and provides mixed evidence for the directional impact of such experiences on individual investors' beliefs and preferences. Evidence on the hot-hand fallacy, for example, suggests that investors extrapolate recent return experiences into the future (Gilovich, Vallone, and Tversky, 1985; De Bondt, 1993; Johnson, Tellis, and Macinnis, 2005), while the gambler's fallacy suggests that investors expect a reversal after good returns (Tversky and Kahneman, 1971; Kroll, Levy, and Rapoport, 1988). As another example of mixed experimental findings, De Bondt (1993) finds a positive relationship between past returns and risk perceptions, while Ganzach (2000) and Shefrin (2001) indicate a negative relationship between past returns and risk perceptions. Overall, the experimental studies do not provide a coherent perspective on how 
investors update their beliefs and preferences as a result of their return and risk experiences. The mixed experimental evidence might result from the lack of a real decision context or the use of participant samples that may not actively invest. Ultimately, how investors update their beliefs and preferences thus becomes an empirical question, which field studies might be better suited to answer than experiments.

Existing field evidence, however, typically focuses on the relation between past returns and return expectations, and proxies for personal return and risk experiences through index returns and/or index volatility. Dominitz and Manski (2011), Greenwood and Shleifer (2014), and Kaplanski et al. (2013) find a positive relation between past index returns and expected returns in household and investor survey data. In contrast, using an event study of investor behavior around September 11, Glaser and Weber (2005) find that return forecasts are higher after a large drop in share prices, suggesting a belief in mean-reversion. Malmendier and Nagel (2011) find a positive relationship between index returns and households' willingness to take risks. Kaplanski et al. (2013) find in their household survey data that past index volatility is negatively related to individuals' index return expectations and positively to their index risk perceptions. Finally, Hoffmann et al. (2013) provide suggestive evidence for a link between index returns and individual investors' return expectations, risk perceptions, and risk tolerance, but the work of these authors leaves open the important research question of how personally experienced returns and risks drive updates in investors' beliefs and preferences.

We provide field evidence on how personal return and risk experiences shape investor beliefs (return expectations and risk perceptions) and preferences (risk tolerance). An important distinction of this paper in comparison to most previous work is that we are able to simultaneously observe direct measures of individual investors' return and risk experiences by 
analyzing their brokerage records and their beliefs and preferences using a panel survey. Moreover, we examine investors' personal return and risk experiences instead of proxying for such experiences by index returns and/or index volatility. This is important, because investors' personal returns can deviate substantially from market returns. Finally, we test in one study the impact of both return and risk experiences on investor beliefs as well as preferences. In so doing, we provide a comprehensive set of results and a coherent view on the behavioral concepts underlying the updating process of investor beliefs and preferences.

\section{Data}

In the analyses of this paper, we exploit a rich dataset, which consists of a unique combination of the brokerage records of 1,376 clients of the largest discount broker in the Netherlands and matching monthly survey data from these investors from April 2008 through March 2009. Because of the richness of the dataset, it lends itself to answering a variety of research questions. Previous analyses of the dataset describe fluctuations in individual investor beliefs and preferences, as well as their behavior, during the 2008-2009 financial crisis (Hoffmann et al., 2013) and show how individual investor beliefs and preferences affect trading and risk-taking behavior (Hoffmann et al., 2015). In this paper, we address a new and different research question, namely how personal return and risk experiences drive updates in individual investors' beliefs and preferences. That is, while previous work on this dataset studied how individual investor beliefs and preferences fluctuate over time and drive behavior, the present paper examines what drives changes in these beliefs and preferences. 


\subsection{Brokerage Records}

Brokerage records are available for investors who completed at least one survey during the sample period. Besides transaction information, the records contain information on investors' daily portfolio balances, demographics such as age and gender, and their six-digit postal code. Based on this postal code, which is unique to each street (or parts of a street), and data retrieved from Statistics Netherlands (Central Bureau of Statistics), we assign income and residential house value to each investor. Table 1 defines all variables. Table 2 shows descriptive statistics of all brokerage accounts available, as well as those for the subset of accounts belonging to clients who completed the survey in each month of the sample period. Table 2 indicates that about $8 \%$ of the clients of which we have survey data and/or brokerage records are male. Their average age is around 50 years and they have an annual disposable income of about $€ 20,000$ (disposable income equals gross income minus taxes, social security contributions, and health insurance premiums). Their average portfolio value at the beginning of the sample period is around $€ 50,000$. The clients are active investors: about half of them traded in each particular month of the sample period, and their annual turnover is over $100 \%$.

\section{[Tables 1 and 2 here]}

A comparison with samples of discount brokerage clients used in other studies of investor behavior in the United States (Barber and Odean, 2000; Barber and Odean, 2002) shows that this study's sample of investors is similar in terms of age and gender, portfolio size, and turnover. ${ }^{1}$ Moreover, according to a report on Dutch retail investors by Millward-Brown (2006), the

\footnotetext{
${ }^{1}$ Although this study's sample appears to be representative for active Dutch retail investors, and is similar to Barber and Odean's $(2000 ; 2002)$ sample of active US retail investors, it might not be typical of Dutch households in general. In particular, compared to the general population of Dutch households, it seems likely that we oversample actively trading individual investors who might have an above-average interest in investing.
} 
account values comprise the major share of investors' total self-managed wealth. As capital gains are not taxed in the Netherlands, tax-loss-selling plays no role in the sample.

\subsection{Survey Design and Data Collection}

At the end of each month between April 2008 and March 2009, a panel of the broker's clients received an email prompting them to complete an online survey. Initially, we invited 20,000 randomly selected clients to participate in our survey, of which 787 did so during the first survey wave of April 2008. The corresponding response rate of 3.9\% $(20,000 / 787 * 100 \%=3.9 \%)$ is in line with those of comparable large-scale surveys (cf. Dorn and Sengmueller, 2009). Six months after the first invitation to participate in our survey, we sent a reminder email to all initially invited clients to maintain a sufficient response rate (October 2008). Hoffmann et al. (2013) compare the investors that responded to the survey to the broker's overall investor population and also perform an analysis of the monthly variation of non-response. Robustness checks based on these comparisons show that the sample is not subject to non-random response problems. Another possible concern is that differences in response timing might affect the results. That is, the return expectations, risk perceptions, and risk tolerance of early versus late respondents might differ, because of quickly changing market conditions. As investors' responses to the survey are clustered within the first few days after each survey email was sent, it is unlikely that there is a response-time pattern in the data that could introduce a possible bias. Indeed, in robustness checks that exclude late respondents, Hoffmann et al. (2013) show that response timing is unlikely to be a concern.

The survey elicited information on investors' return expectations, risk perceptions, and risk tolerance for each upcoming month (see Table 3). We use qualitative measures, as they have 
greater explanatory power for individual decision-making than numerical measures (Kapteyn and Teppa, 2011). In particular, compared to numerical measures, qualitative measures better predict individual preferences among options with unknown outcomes (Windschitl and Wells, 1996), as well as actual (investment) behavior (Dohmen et al., 2011).

[Table 3 here]

Return expectations, risk perceptions, and risk tolerance are measured as in Hoffmann et al. (2013). Return expectations reflect investors' optimism about the returns of their portfolios, risk perceptions reflect investors' interpretations of the riskiness of their portfolios, risk tolerance reflects investors' general predisposition (like or dislike) toward financial risk.

To ensure a reliable measurement instrument, we use multiple items (i.e., survey questions) per variable, include these items in the questionnaire in a random order, and use a mixture of regular- and reverse-scored items (Netemeyer, Bearden, and Sharma, 2003). After adjusting for any reverse-scored items, the final survey measures are computed by equally weighting and averaging their respective item scores. We calculate Cronbach's alphas to examine reliability (Cronbach, 1951). Cronbach's alpha indicates the degree of interrelatedness among a set of items (i.e., survey questions) that together measure a particular variable (e.g., return expectations) and is expressed as a number between 0 and 1. For a variable to be called reliable, Cronbach's alpha should be above 0.7 (Hair et al., 1998). Cronbach's alpha ranges between 0.71 and 0.89 for our measures, thus indicating reliability. Appendix A1.1 contains robustness checks regarding the quality of the used survey measures. 


\section{Empirical Results}

\subsection{Main Results}

We analyze how investors' return and risk experiences impact updates in their beliefs (return expectations and risk perceptions) and preferences (risk tolerance). As a baseline model specification, we run panel regressions with changes in return expectations, risk perceptions, or risk tolerance as the dependent variable. We include investors' past portfolio returns (calculated as the product of the daily relative changes in the value of their portfolio, after transaction costs and adjusting for portfolio in- and outflows) or realized portfolio risk (standard deviation of daily portfolio returns) as explanatory variables that capture their return experiences or risk experiences, respectively. With respect to investor time-invariant effects, we include gender, age, account tenure, income, average portfolio value, and house value as control variables. We include time-variant controls (Derivatives, Traded, Turnover) to capture potential effects of trading activity on the survey measures. Finally, we include month fixed effects to control for unobserved external factors (such as broad market confidence, market returns, etc.) that could impact both the survey measures and the risk and return variables. By including these controls, we can be confident about measuring the distinct effects of personal return and risk experiences on investor beliefs and preferences. Formally, we thus estimate models of the following form:

$$
y_{i t}-y_{i t-1}=\alpha+x_{i t}^{\prime} \beta+\sum_{t=2}^{12} \gamma_{t} d_{t}+u_{i t},
$$

where $y_{i t}-y_{i t-1}$ is the update in investor beliefs or preferences, $x_{i t}^{\prime}$ includes return or risk experiences as well as other control variables, and $d_{t}$ are the time dummy variables. 
As an alternative to our baseline model specification, we estimate models in which the dependent variables constitute levels instead of changes in beliefs and preferences, and that include individual fixed effects. That is, we estimate models of the following form:

$$
y_{i t}=\alpha+x_{i t}^{\prime} \beta+v_{i}+\sum_{t=2}^{12} \gamma_{t} d_{t}+u_{i t}
$$

where $y_{i t}$ are investor beliefs or preferences, $v_{i}$ is the investor-specific intercept, $x_{i t}^{\prime}$ includes return or risk experiences as well as other control variables, and $d_{t}$ are the time dummy variables. Moreover, we estimate the individual fixed effects model including past returns and risk in one regression. Appendix A1.2 contains robustness checks regarding alternative time horizons for past returns and risk.

Table 4 shows that individual investors' return expectations are positively related to their personal return experiences. In the model specification without individual fixed effects (Table 4, Panel A), we document that a 1\% higher experienced return in the last month translates into a .469 higher score on the return expectation scale, which ranges from 1 to $7(p<0.01)$. In the model specification with individual fixed effects (Table 4, Panel B), the corresponding coefficient size is $.427(p<0.01)$. That is, investors update their return expectations according to the hot-hand fallacy and expect what they perceive as trends in returns to continue, as in Gilovich et al. (1985), De Bondt (1993), and Johnson et al. (2005). Based on the theoretical results of Rabin (2002) and Rabin and Vayanos (2010), and on interpreting Burns and Corpus's (2004) and Tyszka et al.'s (2008) experimental results in an investor context, updating return expectations in line with the hot-hand fallacy occurs when investors believe that returns are generated by personal investment skills. The extrapolative type of return expectations updating 
that we find is thus consistent with investors using the representativeness heuristic and believing that personal investment skills drive their returns.

Investors' risk perceptions are negatively related to their return experiences (Table 4). In the model specification without individual fixed effects (Table 4, Panel A), we document that a $1 \%$ higher experienced return in the last month translates into a -.223 lower score on the risk perception scale, which ranges from 1 to $7(p<0.10)$. In the model specification with individual fixed effects (Table 4, Panel B), the corresponding coefficient size is $-.214(p<0.05)$. This finding is consistent with the representativeness and the affect heuristic. That is, Shefrin (2001) argues that because of representativeness, investors expect high returns from safe stocks and low returns from risky stocks. Using their affective associations with a company when forming beliefs about returns and risk, investors assume that "good" stocks are those issued by "good" companies and associate these with both high future returns and safety.

Investors' risk tolerance is positively related to their return experiences in the model specification without individual fixed effects (Table 4, Panel A). In particular, we document that a $1 \%$ higher experienced return in the last month translates into a .186 higher score on the risk tolerance scale, which ranges from 1 to $7(p<0.10)$. This finding is consistent with the housemoney effect of Thaler and Johnson (1990). According to this theory, individuals feel that they can afford to take more risk after experiencing an initial gain when applying a quasi-hedonic editing rule under prospect theory preferences (integrating losses with prior gains, but not with prior losses). Even if these individuals accumulate losses later on, they perceive themselves to be in the positive domain of prospect theory's value function. However, this effect is not present in the individual fixed effects model (Table 4, Panel B). 
[Table 4 here]

Table 5 shows that investors' return expectations, risk perceptions, and risk tolerance are not impacted by their risk experiences. Including both past returns and risk in one regression confirms the previous results (Table 6). Taken together, the results in Tables 4-6 indicate that past returns have an extrapolative impact on return expectations, risk perceptions, and risk tolerance, while the risk of these returns plays no role. Overall, one could interpret our findings as indicating that individual investors care mainly about the returns they achieve, and not about the risk of these returns. Such an interpretation, however, contrasts prior experimental work finding that risk experiences can actually shape beliefs and preferences. This prior experimental evidence about the impact of risk experiences on investor beliefs and preferences suggests that investors' real decision context differs from a lab environment along important dimensions. Real markets, for example, might be more complex and provide investors with less information or noisier signals. If that is the case, more available signals and information that is easier to understand and/or process should be more likely to impact investors' beliefs and preferences. Likewise, more sophisticated investors should be more likely to incorporate information on realized risk than less sophisticated investors. Moreover, experiments typically use participant samples that do not actively invest. When trading with actual money in a real decision context, however, investors might behave more rationally than they do in an experiment. In Sections $3.2-$ 3.5, we examine each of these possibilities.

[Tables 5-6 here] 


\subsection{Return and Risk Experiences: Alternative Measures}

The previous findings suggest that investors care mainly about their returns, but not about the risk of these returns, as measured by their standard deviation. Such an interpretation, however, implicitly assumes that investors are able to calculate a fairly complex risk measure and find it relevant for their decisions. As this assumption might not hold for individual investors, we test several simple alternative risk measures. In addition, we test other well-known measures of riskadjusted returns and risk.

As measures for risk-adjusted returns, we use the one-factor Alpha and the Sharpe ratio. As alternative measures for realized risk, we use the one-factor Beta, the one-factor idiosyncratic volatility, and several downside risk measures (to which the simplest risk measures belong). Prior studies using qualitative surveys or numerical experiments argue that downside risk measures might capture individual investors' interpretation of risk better than do standard symmetric measures of risk, such as the standard deviation of returns. In particular, such studies find evidence that individual investors associate risk with the semivariance of returns, the probability of a loss or a return below a target return, and the potential for a large loss (Slovic, 1967; Olsen, 1997; Unser, 2000; Veld and Veld-Merkoulova, 2008; Vlaev, Chater, and Stewart, 2009). We operationalize the latter two measures by calculating the monthly percentage of returns below a target return ("percent returns below target") and the average of the four largest negative daily returns in a given month ("average of 4 worst returns"). As the target return for calculating the semivariance (i.e., the semi-standard deviation) and the percent returns below target, we use either the return on the Dutch market index (AEX) or a return of $0 \%$. Prior work finds these benchmarks to be the most relevant for individual investors (see e.g., Unser, 2000; Veld and Veld-Merkoulova, 2008). 
With respect to the risk-adjusted return measures, we find that Alpha, like returns, is a strong driver of investor beliefs and preferences. Both variables are highly correlated (Pearson correlation coefficient is 0.72 ), and thus they impact investors in a similar way (see Table 7 , Panel A). In particular, we find that a 1\% higher experienced Alpha in the last month translates into a .410 higher score on the return expectation scale $(p<0.01)$, a -.323 lower score on the risk perception scale $(p<0.01)$, and a .234 higher score on the risk tolerance scale $(p<0.05)$, which all range from 1 to 7 . The Sharpe ratio is relevant for investors' return expectations, but is not a significant predictor for their risk perceptions or risk tolerance (which is not surprising, because the Sharpe ratio combines returns with the complex measure standard deviation). In particular, a one-unit increase in last month's Sharpe ratio translates into a .205 higher score on the return expectation scale, which ranges from 1 to $7(p<0.01)$.

[Table 7 here]

Realized systematic risk (Beta), idiosyncratic risk, and the semi-standard deviation of returns are not significant predictors of investor beliefs and preferences (see Table 7, Panel B). Relatively simple downside risk measures, such as the percentage of returns below a target return, and the average of an investor's four worst returns, however, are significant predictors of changes in investors' return expectations: A larger percentage of returns that lie below the target return decreases investors' return expectations, while a larger average of the four worst negative returns (i.e., a less negative number) increases investors' return expectations. In particular, a 1\% larger percentage of returns that lie below the index return (zero return) translates into a $-.683(-.587)$ lower score on the return expectation scale, which ranges from 1 to 7 ( $p<0.01)$. Finally, a $1 \%$ 
larger average of the four worst negative returns translates into a .135 higher score on the return expectation scale, which ranges from 1 to $7(p<0.10)$.

\subsection{Availability of Return and Risk Signals}

According to Tversky and Kahneman's (1973) availability heuristic, the extent to which individuals incorporate information depends on the ease with which it comes to mind. If our finding that investors' return expectations, risk perceptions, and risk tolerance are driven by their return experiences, but not by their risk experiences, is related to the availability of these two signals, we would expect investors who examine their portfolios more often to have a better idea about the risk they experience (i.e., they would be more likely to observe fluctuations in their portfolios, which would improve their ability to estimate the return standard deviation). We do not have access to brokerage data about investors' login frequency. Therefore, we use investors' trading activity as a proxy for the frequency with which they examine their portfolios (i.e., assuming that investors' trading activity is related to looking at their portfolios, as buying or selling a security requires investors to login to the brokerage system). We run several regressions in which we interact indicators for trading activity (having traded, indicator variables for turnover quartiles) with past returns and realized risk. These regressions do not yield significant results. This may be because trading activity is an imperfect proxy for the frequency with which investors look at their portfolios or because trading activity is typically inversely related to investment skills (see e.g., Barber and Odean, 2000; Grinblatt and Keloharju, 2009; Graham, Harvey, and Huang, 2009). That is, although investors who trade more frequently may look at their portfolios more often, they may also have inferior investment skills and be more prone to 
behavioral biases, which could include a tendency to ignore relevant information, such as the risk of their portfolio's returns.

We have further data on investors' ability to observe their portfolios and their returns. Based on a survey question that asks investors to report the sign of their past portfolio return, we find that investors with returns that are close to zero have difficulty reporting the correct sign. Investors with large positive or negative returns, that are potentially more available in their minds, however, are better in reporting the correct sign of their return. Thus, availability seems to play a role in investors' ability to observe signals. Furthermore, in explaining the results on risk experiences, framing may play a role. That is, in the interface design of a typical brokerage system, only information on past returns is readily available. Investors must look up themselves information on the realized risk of each portfolio component, and to determine the risk of the complete portfolio, make relatively complex calculations. For many individual investors, this may require too much effort. Thus, they rely primarily on easily available past return information, consistent with prior work on framing and the availability heuristic (Tversky and Kahneman, 1973; Tversky and Kahneman, 1981; Kühberger, 1998).

\subsection{Investor Experience and Sophistication}

Experience and sophistication are key characteristics influencing investor behavior (Agnew, 2006) that could also affect the formation of investor beliefs and preferences. To examine the possible impact of these investor characteristics, we run the same regression models as before, but include interaction terms for past returns and realized risk with variables that prior literature shows to be proxies for investor experience and sophistication. In particular, we use interaction terms for derivatives trading (Bauer et al., 2009; Seru, Shumway, and Stoffman, 2010), age 
(Korniotis and Kumar, 2011b; Korniotis and Kumar, 2013), account tenure (Seru et al., 2010), income (Dhar and Zhu, 2006), and wealth, proxied by the combined value of an investor's portfolio and house (Vissing-Jorgensen, 2003; van Rooij et al., 2011).

The interactions with wealth and trading derivatives, and most of the interactions with age, account tenure, and income, are not significant and not reported. For the other interactions, Tables 8 and 9 report the coefficients for the main effect and interaction term.

\section{[Tables 8-9 here]}

The overall pattern of results indicates that investors who are more experienced (longer account tenure) and more sophisticated (not in the highest age quartile, within the highest income quartile) update their return expectations, risk perceptions, and risk tolerance in a way that reflects a weaker belief in trend continuation and personal investment skills as the driver of their returns, as well as a weaker house-money effect. At the same time, sophisticated investors are also less prone to looking at past returns alone. In particular, the risk tolerance of investors in the top $50 \%$ of the income distribution is hardly impacted at all by their past returns. That is, more sophisticated investors are almost not at all subject to the house-money effect. Similar moderating patterns appear for account tenure. Consistent with Korniotis and Kumar (2011b; 2013), investors that do not belong to the highest age quartile (and thus have higher cognitive skills), have a weaker tendency to extrapolate past returns into the future (Table 8). Most importantly, realized risk matters for experienced investors: Investors with longer account tenure increase their risk perception after experiencing more risk (Table 9). 


\subsection{Rationality of Updates in Beliefs}

Although returns are generally nearly unpredictable on a monthly basis (Welch and Goyal, 2008), while risk is predictable (Andersen et al., 2001), it could be rational for investors to extrapolate past returns, but not risk, if in our sample past returns are informative for future returns (and risk), but realized risk provides no predictive power for future returns (and risk).

Investors' returns might exhibit momentum and/or investors could learn from their past returns in the sense that increased return expectations reflect that they have gained knowledge about their personal investment skills. If (one of) these explanations holds true, it would be rationally justified for these investors to expect good returns to continue. To test these possibilities, we first check whether in our sample past returns are predictive of future returns or risk. We then test whether high return expectations (potentially indicating learning about personal investment skills) predict higher future returns (in which case investors' expectations would be rationally justified). We first regress current returns on past returns. We find a positive (0.026) but insignificant coefficient $(p=0.526)$ for past returns. The regression of current realized risk (standard deviation) on past returns yields a negative coefficient $(-0.121)$, which is again insignificant $(p=0.228)$. When we run a regression of current returns on past return expectations, the effect is also insignificant (coefficient for past return expectations is $0.003, p=$ 0.385). We thus conclude that for the investors in our sample, past returns do not provide information on future returns or risk that would rationally justify extrapolative expectations from past returns to future returns and risk.

As a next test on the rationality of investors' beliefs updating, we check whether in our sample past volatility predicts future volatility. When we regress current volatility on past volatility, the regression coefficient $(0.755, p=0.000)$ indicates that past volatility is indeed 
informative for current volatility. Thus, for a rational investor, we should expect to find an effect of realized volatility on risk perceptions, which, however, is not the case.

\section{Conclusion and Discussion}

Using unique panel data from active individual investors, we provide field evidence of the directional impact of both return and risk experiences on investor beliefs and preferences. We find that investors' return experiences drive updates in beliefs, and to some extent also updates in preferences. That is, past returns positively impact return expectations and negatively impact risk perceptions. We also find a positive impact of past returns on risk tolerance, but only in some model specifications. The risk of these past returns, however, is not related to changes in return expectations, risk perceptions, or risk tolerance when examining standard risk measures, such as the standard deviation of returns.

The absence of an effect of realized risk is related to the complexity of standard risk measures, investor sophistication, and potentially to the lower availability of return signals compared to risk signals. When defining risk in terms of simple downside risk measures that are closely related to past returns, we do find a negative impact of risk experiences on return expectations. The tendency to look primarily at past returns is pronounced among inexperienced and unsophisticated investors. These investors might find it difficult to interpret portfolio risk, and use portfolio returns as a more easily available performance metric. We do not find evidence that this updating process is compatible with a rational benchmark. Rather, return and risk experiences influence investors' beliefs and preferences consistent with predictions from the representativeness heuristic, the affect heuristic, and the availability heuristic. Given that we examine a sample of rather active and experienced individual investors, which should be more 
familiar with the notion of risk than the average Dutch household, our findings on the failure to incorporate risk experiences when updating beliefs are potentially even more pronounced in the general population.

The results of this paper help explain the stylized fact that past fund returns are positively related to fund flows, while past risk has no impact, except for sophisticated investors (Sirri and Tufano, 1998; Huang et al., 2012; Chalmers et al., 2013). As past returns shape return expectations, risk perceptions, and risk tolerance, and these variables drive investors' trading and risk-taking behavior, past returns drive fund flows. As standard measures of past risk are not related to changes in return expectations, risk perceptions, and risk tolerance, however, risk has no impact on fund flows. Furthermore, the extrapolative impact of past returns on subsequent changes in investor beliefs and preferences helps to explain the creation of asset-price bubbles. The experiments of Hommes et al. $(2005 ; 2008)$ show that such bubbles occur when individuals have trend-following expectations. Our results provide field evidence for the existence of these conditions in financial markets.

As to the practical implications and relevance of our study, Bateman et al. (2011) note the worldwide shift towards individual pension accounts and the heavy choice burden that this move puts on individuals. For example, these authors report that Australian employees must (subject to the availability of default options) decide on investment of their mandatory retirement savings contributions, choosing from up to 2,000 managed funds. The question is whether all individuals are ready to cope with this choice burden and the according transfer of risk and responsibility of retirement saving and investment decisions from plan sponsors to individuals. The recent work by Earl et al. (2015), Gerrans and Yap (2014), and Gan et al. (2014) on the financial literacy of (Australian) pension plan participants suggest various challenges in this regard. The results of 
our study add to this collection of work by suggesting that individuals likely have difficulties grasping the concept of (financial) risk, at least in the way that it is typically operationalized in finance theory and the financial industry. Butt et al. (2015) interviewed Australian fund executives on the implementation of MySuper, a regulatory framework for default retirement savings funds that providers were required to have in place by the beginning of 2014. Although these authors document an evolvement towards a better alignment of providers' purpose and motivation with perceived member interests, they also note that the standard risk measures of providers are a poor representation of how participants perceive risk, which is consistent with this study's results on individual investors' difficulty of understanding risk and including it in the updating of their beliefs.

As a potential limitation of our study, we note that our sample period is from April 2008 through March 2009. On the one hand, this is beneficial for examining the effect of investors' realized portfolio returns and risk on subsequent changes in their beliefs and preferences, as there is substantial variation in beliefs and preferences, as well as in portfolio returns and risk. On the other hand, our sample period corresponds to a relative volatile market period, and investors may update their beliefs and preferences less in more tranquil times. In particular, investors' risk perceptions may be more stable in non-crisis periods. Future research should therefore examine the generalizability of our findings across time. 


\section{Appendix A1: Robustness Checks}

\section{A1.1 Quality of the Survey Measures}

As the survey measures of investor return expectations, risk perceptions, and risk tolerance are central to our analyses, it is important to validate their quality. A potential concern in this regard is that investors may not be aware of their return and risk experiences. In that case, changes in beliefs and preferences could be driven by unobserved factors instead of investors' actual return and risk experiences. We have access to an additional survey question that allows us to directly check for potential problems in this regard. Specifically, from October 2008 through March 2009, investors responded to the following statement: "This month, I made a positive return." Investors' responses to this question were recorded on a seven-point Likert scale, ranging from 1 $=$ totally agree to $7=$ totally disagree, with the scale midpoint (category 4 ) labeled "neutral." We

recode this survey variable into a new variable indicating whether investors correctly reported the sign of their return experience: Whenever an investor agreed with the statement (categories 1 to 3 ) and had a positive return or disagreed with the statement (categories 5 to 7) and had a negative return, we count this as a correct identification of the sign of the realized return; otherwise, we record an incorrect identification of the return sign.

It is not obvious how category 4 ("neutral") should be treated. To be conservative, we first treat all such responses as being in the incorrect sign category. Based on this conservative classification, $72.11 \%$ percent of investors correctly identify the sign of the return they realized over the past month. As an alternative classification, we exclude from the sample the responses in the "neutral" category, as well as observations where realized returns are very close to zero (between -1 and +1 percent). That is, we exclude those returns where it is likely that investors respond correctly or incorrectly just by accident. Based on this less conservative classification, 
$83.85 \%$ of investors give a correct response to the survey question. Thus, over a one-month time horizon, which is the primary focus of our analysis, most investors have a good idea of their performance in terms of the sign of their past returns.

In addition, we have supporting evidence from another survey variable, where we asked investors from October 2008 through March 2009 to report their number of transactions in the last month. The difference between the self-reported and the actual number of trades is only +0.14 , on average, and statistically indistinguishable from zero $(p=0.77)$.

In conclusion, responses to both the sign of the past returns question and the last month's number of trades question indicate that most investors in the sample are well aware of their recent performance and trading activity.

Another potential concern with respect to the quality of the survey measures is that they are measured on a Likert scale that ranges from 1 to 7 . Thus, investors that have responses at or close to the scales' upper or lower limit in a certain month might not be able to express updates in their beliefs and preferences for the next month appropriately. Hence, to test the robustness of the results, we exclude all observations where return expectation, risk perception, or risk tolerance values are smaller than 2 or larger than 6 and estimate the models of Section 3.1 again on the resulting subsample, which includes $84 \%$ of observations in the original sample. The results are consistent with the previous findings reported in Section 3.1: Past returns impact changes in beliefs and preferences in the same way as before (similar coefficient magnitudes and levels of significance), while we do not find an effect of realized risk on changes in beliefs and preferences (detailed results available upon request).

A final concern relates to the wording of the survey questions eliciting return expectations. Although the Cronbach's alpha of the overall return expectations construct (consisting of five 
items) indicates it is a reliable measure (see Section 2.2), one could claim that only the fourth item of this scale measures return expectations per se, while the other items pick up more general investor optimism. To check for this possibility, we repeat the main analysis, now including only the fourth item in the return expectations measure. The results from this specification are consistent with the previous ones: In the return expectation regression, the coefficient for past returns is 0.39 and significant $(p<0.01)$, while the coefficient for realized risk is 0.001 and insignificant $(p=0.98$, compare Tables 4-5).

\section{A1.2 Alternative Time Horizons}

In the main analyses, we test the impact of the last month's return and risk on changes in investor beliefs and preferences, finding that past returns are an important determinant thereof but that realized risk is not. To assess the robustness of these findings, in the following, we test the effect of using different time horizons for past returns and risk. In particular, we run the same regression models as in Section 3.1, but instead of using information on the returns and risk of the past month, we use information on the past 60,20 , and 10 days. Results obtained from these alternative specifications are consistent with the findings reported in Section 3.1: Past returns are an important predictor of investors' beliefs and preferences (Table A1.1), whereas risk is not (detailed results available upon request). 
Table A1.1

Impact of Past Return on Changes in Survey Measures-Alternative Past Return Windows

\begin{tabular}{|c|c|c|c|c|c|c|}
\hline \multirow[t]{2}{*}{ Dependent Variable } & \multicolumn{2}{|c|}{$\Delta$ Return Expectation } & \multicolumn{2}{|c|}{$\Delta$ Risk Perception } & \multicolumn{2}{|c|}{$\Delta$ Risk Tolerance } \\
\hline & Coef. & Std. err. & Coef. & Std. err. & Coef. & Std. err. \\
\hline Return past 60 days & 0.467 & $0.077 * * *$ & -0.007 & 0.120 & 0.291 & $0.091 * * *$ \\
\hline Return past month (baseline) & 0.469 & $0.086 * * *$ & -0.223 & $0.133 *$ & 0.186 & $0.110 *$ \\
\hline Return past 20 days & 0.460 & $0.080 * * *$ & -0.296 & $0.122 * *$ & 0.056 & 0.098 \\
\hline Return past 10 days & 0.452 & $0.069 * * *$ & -0.241 & $0.105 * *$ & 0.063 & 0.082 \\
\hline
\end{tabular}

This table presents the results from regressions of changes in investor return expectation, risk perception, or risk tolerance on past investor returns and a set of control variables. The columns show results of the same panel models previously used in Table 4 (Panel A), with alternative windows for past returns. Each line reported refers to an alternative model specification (separate regression). All returns are scaled to refer to monthly terms, except for the past 60 days regressions. Here, returns are scaled to two monthly terms and consistent with that scale, the dependent variable is the change in return expectation (or risk perception, risk tolerance) over the last two months. Variables are defined in Table 1. Standard errors are clustered on the investor level. *, **, and *** denote statistical significance at the $10 \%, 5 \%$, and $1 \%$ levels, respectively.

This analysis provides some additional insights. In particular, the coefficients for past returns become more significant in the risk-perception regression for shorter time windows, while the opposite occurs for risk tolerance. These results complement previous empirical evidence obtained with household data by Malmendier and Nagel (2011) as well as Greenwood and Shleifer (2014) that more recent experiences matter more in the formation of beliefs. Furthermore, these results extend Bateman et al.'s (2011) finding that investors' preferences (risk tolerance) are relatively stable, in that we find that such preferences are impacted more by long-term experiences than by short-term ones. 


\section{References}

Agnew, J. R., 2006, Do Behavioral Biases Vary Across Individuals? Evidence from Individual Level 401(k) Data, Journal of Financial and Quantitative Analysis 41, 939-962.

Andersen, T. G., T. Bollerslev, F. X. Diebold, and H. Ebens, 2001, The Distribution of Realized Stock Return Volatility, Journal of Financial Economics 61, 43-76.

Barber, B. M. and T. Odean, 2000, Trading is Hazardous to Your Wealth: the Common Stock Investment Performance of Individual Investors, Journal of Finance 55, 773-806.

Barber, B. M. and T. Odean, 2002, Online Investors: Do the Slow Die First?, Review of Financial Studies 15, 455-487.

Barber, B. M., T. Odean, and N. Zhu, 2009, Do Retail Trades Move Markets?, Review of Financial Studies 22, 151-186.

Bateman, H., J. Louviere, S. Satchell, T. Islam, and S. Thorp, 2011, Retirement Investor Risk Tolerance in Tranquil and Crisis Periods: Experimental Survey Evidence, Journal of Behavioral Finance 12, 201-218.

Bauer, R., M. Cosemans, and P. M. A. Eichholtz, 2009, Option Trading and Individual Investor Performance, Journal of Banking and Finance 33, 731-746.

Benson, K., P. M. Clarkson, T. Smith, and I. Tutticci, 2015, A Review of Accounting Research in the Asia Pacific Region, Australian Journal of Management 40, 36-88.

Benson, K., R. Faff, and T. Smith, 2014, Fifty Years of Finance Research in the Asia Pacific Basin, Accounting and Finance 54, 335-363.

Blasco, N., P. Corredor, and S. Ferreruela, 2012, Market Sentiment: A Key Factor of Investors' Imitative Behaviour, Accounting and Finance 52, 663-689. 
Bowman, R. G. and J. Buchanan, 1995, The Efficient Market Hypothesis: A Discussion of Institutional, Agency and Behavioural Issues, Australian Journal of Management 20, 155166.

Burns, B. D. and B. Corpus, 2004, Randomness and Inductions from Streaks: "Gambler's Fallacy" versus "Hot Hand", Psychonomic Bulletin and Review 11, 179-184.

Butt, A., M. S. Donald, F. D. Foster, S. Thorp, and G. J. Warren, 2015, Design of MySuper Default Funds: Influences and Outcomes, Accounting and Finance forthcoming.

Chalmers, J., A. Kaul, and B. Phillips, 2013, The Wisdom of Crowds: Mutual Fund Investors' Aggregate Asset Allocation Decision, Journal of Banking and Finance 37, 3318-3333.

Cronbach, L. J., 1951, Coefficient Alpha and the Internal Structure of Tests, Psychometrika 16, 297-334.

De Bondt, W. F. M., 1993, Betting on Trends: Intuitive Forecasts of Financial Risk and Return, International Journal of Forecasting 9, 355-371.

Dhar, R. and N. Zhu, 2006, Up Close and Personal: Investor Sophistication and the Disposition Effect, Management Science 52, 726-740.

Dohmen, T. J., A. Falk, D. Huffman, U. Sunde, J. Schupp, and G. G. Wagner, 2011, Individual Risk Attitudes: New Evidence from a Large, Representative, Experimentally-Validated Survey, Journal of the European Economic Association 9, 522-550.

Dominitz, J. and C. F. Manski, 2011, Measuring and Interpreting Expectations of Equity Returns, Journal of Applied Econometrics 26, 352-370.

Dorn, D. and P. Sengmueller, 2009, Trading as Entertainment?, Management Science 55, 591603. 
Earl, J., P. Gerrans, and A. Asher, 2015, Financial Literacy, Financial Judgement, and Retirement Self-Efficacy of Older Trustees of Self-Managed Superannuation Funds, Australian Journal of Management forthcoming.

Foucault, T., D. Sraer, and D. J. Thesmar, 2011, Individual Investors and Volatility, Journal of Finance 66, 1369-1406.

Gan, S., R. Heaney, and P. Gerrans, 2014, Individual Investor Portfolio Performance in Retirement Savings Accounts, Australian Journal of Management forthcoming.

Ganzach, Y., 2000, Judging Risk and Return of Financial Assets, Organizational Behavior and Human Decision Processes 83, 353-370.

Gerrans, P., R. Faff, and N. Hartnett, 2015, Individual Financial Risk Tolerance and the Global Financial Crisis, Accounting and Finance 55, 165-185.

Gerrans, P. and G. Yap, 2014, Retirement Savings Investment Choices: Sophisticated or Naïve?, Pacific-Basin Finance Journal 30, 233-250.

Gilovich, T., R. Vallone, and A. Tversky, 1985, The Hot Hand in Basketball: On the Misperception of Random Sequences, Cognitive Psychology 17 295-314.

Glaser, M. and M. Weber, 2005, September 11 and Stock Return Expectations of Individual Investors, Review of Finance 9, 243-279.

Graham, J. R., C. R. Harvey, and H. Huang, 2009, Investor Competence, Trading Frequency, and Home Bias, Management Science 55, 1094-1106.

Greenwood, R. and A. Shleifer, 2014, Expectations of Returns and Expected Returns, Review of Financial Studies 27, 714-746.

Grinblatt, M. and M. Keloharju, 2009, Sensation Seeking, Overconfidence, and Trading Activity, Journal of Finance 64, 549-578. 
Hair, J. F., R. E. Anderson, R. L. Tatham, and W. C. Black, 1998, Multivariate Data Analysis (Upper Saddle River, New Jersey: Prentice Hall).

Han, B. and A. Kumar, 2013, Speculative Retail Trading and Asset Prices, Journal of Financial and Quantitative Analysis 48, 377-404.

Harding, N. and W. He, 2015, Investor Mood and the Determinants of Stock Prices: An Experimental Analysis, Accounting and Finance forthcoming.

Hirshleifer, D., 2001, Psychology and Asset Pricing, Journal of Finance 56, 1533-1597.

Hoffmann, A. O. I., T. Post, and J. M. E. Pennings, 2013, Individual Investor Perceptions and Behavior During the Financial Crisis, Journal of Banking and Finance 37, 60-74.

Hoffmann, A. O. I., T. Post, and J. M. E. Pennings, 2015, How Investor Perceptions Drive Actual Trading and Risk-Taking Behavior, Journal of Behavioral Finance 16, 94-103.

Hommes, C. H., J. Sonnemans, J. Tuinstra, and H. van de Velden, 2005, Coordination of Expectations in Asset Pricing Experiments, Review of Financial Studies 18, 955-980.

Hommes, C. H., J. Sonnemans, J. Tuinstra, and H. van de Velden, 2008, Expectations and Bubbles in Asset Pricing Experiments, Journal of Economic Behavior and Organization 67, 116-133.

Huang, J., K. D. Wei, and H. Yan, 2012, Investor Learning and Mutual Fund Flows, Working paper (University of Texas at Austin).

Johnson, J., G. J. Tellis, and D. J. Macinnis, 2005, Losers, Winners, and Biased Trades, Journal of Consumer Research 32, 324-329.

Kaplanski, G., H. Levy, C. Veld, and Y. V. Veld-Merkoulova, 2013, Do Happy People Make Optimistic Investors?, Journal of Financial and Quantitative Analysis 50, 145-168. 
Kapteyn, A. and F. Teppa, 2011, Subjective Measures of Risk Aversion, Fixed Costs, and Portfolio Choice, Journal of Economic Psychology 32, 564-580.

Kogan, L., S. A. Ross, J. Wang, and M. M. Westerfield, 2006, The Price Impact and Survival of Irrational Traders, Journal of Finance 61, 195-229.

Korniotis, G. M. and A. Kumar, 2011a, Do Behavioral Biases Adversely Affect the MacroEconomy?, Review of Financial Studies 24, 1513-1559.

Korniotis, G. M. and A. Kumar, 2011b, Do Older Investors Make Better Investment Decisions?, Review of Economics and Statistics 93, 244-265.

Korniotis, G. M. and A. Kumar, 2013, Do Portfolio Distortions Reflect Superior Information or Psychological Biases?, Journal of Financial and Quantitative Analysis 48, 1-45.

Kroll, Y., H. Levy, and A. Rapoport, 1988, Experimental Tests of the Mean-Variance Model for Portfolio Selection, Organizational Behavior and Human Decision Processes 42, 388-410.

Kühberger, A., 1998, The Influence of Framing on Risky Decisions: A Meta-analysis, Organizational Behavior and Human Decision Processes 75, 23-55.

Kumar, A. and C. Lee, 2006, Retail Investor Sentiment and Return Comovements, Journal of Finance 61, 2451-2486.

Malmendier, U. and S. Nagel, 2011, Depression Babies: Do Macroeconomic Experiences Affect Risk-Taking?, Quarterly Journal of Economics 126, 373-416.

Millward-Brown (2006), The Retail Investor 2006: Developments in the Market of Retail Investors in the Netherlands (Amsterdam, The Netherlands).

Netemeyer, R. G., W. O. Bearden, and S. Sharma, 2003, Scaling Procedures: Issues and Applications (Thousand Oaks, California: Sage Publications). 
Olsen, R. A., 1997, Investment Risk: The Experts' Perspective, Financial Analysts Journal 53, 62-66.

Rabin, M., 2002, Inference by Believers in the Law of Small Numbers, Quarterly Journal of Economics 117, 775-816.

Rabin, M. and D. Vayanos, 2010, The Gambler's Fallacy and Hot-Hand Fallacies: Theory and Applications, Review of Economic Studies 77, 730-778.

Seru, A., T. Shumway, and N. Stoffman, 2010, Learning by Trading, Review of Financial Studies 23, 705-739.

Shefrin, H., 2001, Do Investors Expect Higher Returns from Safer Stocks than from Riskier Stocks?, Journal of Psychology and Financial Markets 2, 176-181.

Shu, P.-G., T.-L. Yeh, T.-L. Chiang, and J.-Y. Hung, 2013, Managerial Overconfidence and Share Repurchases, International Review of Finance 13, 39-65.

Sirri, E. R. and P. Tufano, 1998, Costly Search and Mutual Fund Flows, Journal of Finance 53, 1589-1622.

Slovic, P., 1967, The Relative Influence of Probabilities and Payoffs Upon Perceived Risk of A Gamble, Psychonomic Science 9, 223-224.

Thaler, R. H. and E. J. Johnson, 1990, Gambling With the House Money and Trying to Break Even: The Effects of Prior Outcomes on Risky Choice, Management Science 36, 643-660.

Tourani-Rad, A. and S. Kirkby, 2005, Investigation of Investors' Overconfidence, Familiarity and Socialization, Accounting and Finance 45, 283-300.

Tversky, A. and D. Kahneman, 1971, Belief in the Law of Small Numbers, Psychological Bulletin 76, 105-10. 
Tversky, A. and D. Kahneman, 1973, Availability: A Heuristic for Judging Frequency and Probability, Cognitive Psychology 5, 207-232.

Tversky, A. and D. Kahneman, 1981, The Framing of Decisions and the Psychology of Choice, Science 211, 453-458.

Tyszka, T., P. Zielonka, R. Dacey, and P. Sawicki, 2008, Perception of Randomness and Predicting Uncertain Events, Thinking and Reasoning 14, 83-110.

Unser, M., 2000, Lower Partial Moments as Measures of Perceived Risk: An Experimental Study, Journal of Economic Psychology 21, 253-280.

van Rooij, M., A. Lusardi, and R. Alessie, 2011, Financial Literacy and Stock Market Participation, Journal of Financial Economics 101, 449-472.

Veld, C. and Y. V. Veld-Merkoulova, 2008, The Risk Perceptions of Individual Investors, Journal of Economic Psychology 29, 226-252.

Vissing-Jorgensen, A., 2003, Perspectives On Behavioral Finance: Does "Irrationality" Disappear With Wealth? Evidence From Expectations And Actions, in NBER Macroeconomics Annual 2003, M. Gertler and K. Rogoff, eds. Boston: MIT Press, 139-194.

Vlaev, I., N. Chater, and N. Stewart, 2009, Dimensionality of Risk Perception: Factors Affecting Consumer Understanding and Evaluation of Financial Risk, Journal of Behavioral Finance $10,158-181$.

Welch, I. and A. Goyal, 2008, A Comprehensive Look at The Empirical Performance of Equity Premium Prediction, Review of Financial Studies 21, 1455-1508.

Windschitl, P. D. and G. L. Wells, 1996, Measuring Psychological Uncertainty: Verbal Versus Numeric Methods, Journal of Experimental Psychology 2, 343-364. 
Table 1

\section{Variable Definitions}

\begin{tabular}{|c|c|}
\hline Variable & Definition \\
\hline Gender & Indicator variable taking the value 0 for male investors and 1 for female investors. \\
\hline Age & Age of the investor in years as of April 2008. \\
\hline Account Tenure & Number of years the investor is already client of the brokerage firm as of April 2008. \\
\hline Income & $\begin{array}{l}\text { Annual disposable income in } 2007 \text { (equals gross income minus taxes, social security } \\
\text { contributions, and health insurance premiums paid). Assigned to each investor based } \\
\text { on her 6-digit postal code. This postal code is unique for each street in the } \\
\text { Netherlands. Data source is the average net income per 6-digit postal code from } \\
\text { Statistics Netherlands (Central Bureau of Statistics). }\end{array}$ \\
\hline Portfolio Value & Value of the investment assets in an investor's account at the end of the month. \\
\hline House Value & $\begin{array}{l}\text { Value of the house in } 2008 \text {. Assigned to each investor based on his or her 6-digit } \\
\text { postal code. This postal code is unique for each street in the Netherlands. Data source } \\
\text { is the average residential house value per 6-digit postal code from Statistics } \\
\text { Netherlands (Central Bureau of Statistics). }\end{array}$ \\
\hline Derivatives & $\begin{array}{l}\text { Indicator variable taking the value } 1 \text { if an investor traded an option or futures contract } \\
\text { at least once during a particular month; } 0 \text { otherwise. }\end{array}$ \\
\hline Traded & $\begin{array}{l}\text { Indicator variable taking the value } 1 \text { if an investor traded in a particular month; } 0 \\
\text { otherwise. }\end{array}$ \\
\hline Turnover & $\begin{array}{l}\text { Average of the absolute values of all purchases and sales in a particular month, } \\
\text { divided by the average of the portfolio values at the beginning and end of a particular } \\
\text { month. }\end{array}$ \\
\hline Return & $\begin{array}{l}\text { Monthly investor return given by the product of the daily relative changes in the value } \\
\text { of his or her portfolio, after transaction costs and adjusting for portfolio in- and } \\
\text { outflows. For example, a monthly return of } 10 \% \text { takes the value } 0.1 \text { in the data. }\end{array}$ \\
\hline Std(Return) & $\begin{array}{l}\text { Investor-specific standard deviation of daily portfolio returns in a particular month (in } \\
\text { monthly terms). }\end{array}$ \\
\hline Alpha & One-factor alpha (Jensen's alpha) in a particular month (in monthly terms). \\
\hline Beta & One-factor beta in a particular month. \\
\hline Idiosyncratic Volatility & $\begin{array}{l}\text { Standard deviation of the residuals in the one-factor model regression (in monthly } \\
\text { terms). }\end{array}$ \\
\hline Sharpe Ratio & Monthly return divided by the standard deviation of return (in monthly terms). \\
\hline $\begin{array}{l}\text { Semi-standard deviation } \\
\text { (Index Return) }\end{array}$ & $\begin{array}{l}\text { Standard deviation of daily portfolio returns below the target return in a particular } \\
\text { month (in monthly terms). Target return is the return on the Dutch stock market index } \\
\text { AEX. }\end{array}$ \\
\hline $\begin{array}{l}\text { Semi-standard deviation } \\
\text { (Zero Return) }\end{array}$ & $\begin{array}{l}\text { Standard deviation of daily portfolio returns below the target return in a particular } \\
\text { month (in monthly terms). Target return is a return of } 0 \% \text {. }\end{array}$ \\
\hline $\begin{array}{l}\text { Percent Returns below } \\
\text { Target (Index Return) }\end{array}$ & $\begin{array}{l}\text { Monthly percentage of daily portfolio returns that are below the target return. Target } \\
\text { return is the return on the Dutch stock market index AEX. }\end{array}$ \\
\hline $\begin{array}{l}\text { Percent Returns below } \\
\text { Target (Zero Return) }\end{array}$ & $\begin{array}{l}\text { Monthly percentage of daily portfolio returns that are below the target return. Target } \\
\text { return is a return of } 0 \% \text {. }\end{array}$ \\
\hline $\begin{array}{l}\text { Average of } 4 \text { Worst } \\
\text { Returns }\end{array}$ & $\begin{array}{l}\text { Average of the four largest negative daily returns in a given month (in monthly } \\
\text { terms). }\end{array}$ \\
\hline Return Expectation & $\begin{array}{l}\text { Reflects how optimistic a respondent is about his or her investment portfolio and its } \\
\text { returns in the upcoming month. Details on the survey questions are given in Table } 3 \text {. }\end{array}$ \\
\hline Risk Perception & $\begin{array}{l}\text { Reflects a respondent's interpretation of how risky the stock market will be in the } \\
\text { upcoming month. Details on the survey questions are given in Table } 3 \text {. }\end{array}$ \\
\hline Risk Tolerance & Reflects a respondent's general predisposition toward financial risk. Details on the \\
\hline
\end{tabular}


survey questions are given in Table 3.

Because of data availability, the data retrieved from Statistics Netherlands refer to different years, that is, to 2007 for income and to 2008 for house value. 
Table 2

Descriptive Statistics

\begin{tabular}{|c|c|c|c|c|c|c|c|c|c|c|c|c|c|}
\hline \multirow[b]{2}{*}{ Month } & & \multicolumn{12}{|c|}{ Panel A: All Brokerage Accounts } \\
\hline & & Apr-08 & May-08 & Jun-08 & Jul-08 & Aug-08 & Sep-08 & Oct-08 & Nov-08 & Dec-08 & Jan-09 & Feb-09 & Mar-09 \\
\hline Investors & $\mathrm{N}$ & 1,376 & 1,376 & 1,376 & 1,376 & 1,376 & 1,376 & 1,376 & 1,376 & 1,376 & 1,376 & 1,376 & 1,376 \\
\hline Gender (Fraction Female) & mean & 0.08 & 0.08 & 0.08 & 0.08 & 0.08 & 0.08 & 0.08 & 0.08 & 0.08 & 0.08 & 0.08 & 0.08 \\
\hline \multirow[t]{2}{*}{ Age in Years } & mean & 50.56 & 50.56 & 50.56 & 50.56 & 50.56 & 50.56 & 50.56 & 50.56 & 50.56 & 50.56 & 50.56 & 50.56 \\
\hline & std & 13.57 & 13.57 & 13.57 & 13.57 & 13.57 & 13.57 & 13.57 & 13.57 & 13.57 & 13.57 & 13.57 & 13.57 \\
\hline \multirow[t]{2}{*}{ Account Tenure } & mean & 4.07 & 4.07 & 4.07 & 4.07 & 4.07 & 4.07 & 4.07 & 4.07 & 4.07 & 4.07 & 4.07 & 4.07 \\
\hline & std & 2.77 & 2.77 & 2.77 & 2.77 & 2.77 & 2.77 & 2.77 & 2.77 & 2.77 & 2.77 & 2.77 & 2.77 \\
\hline \multirow[t]{2}{*}{ Income $€$} & mean & 20,242 & 20,242 & 20,242 & 20,242 & 20,242 & 20,242 & 20,242 & 20,242 & 20,242 & 20,242 & 20,242 & 20,242 \\
\hline & std & 4,314 & 4,314 & 4,314 & 4,314 & 4,314 & 4,314 & 4,314 & 4,314 & 4,314 & 4,314 & 4,314 & 4,314 \\
\hline \multirow[t]{2}{*}{ Portfolio Value $€$} & mean & 52,854 & 52,695 & 44,872 & 42,840 & 45,963 & 37,688 & 31,127 & 30,100 & 30,679 & 29,564 & 26,514 & 27,875 \\
\hline & std & 156,058 & 156,096 & 134,883 & 127,338 & 135,203 & 117,935 & 101,325 & 104,663 & 105,279 & 99,322 & 91,598 & 92,307 \\
\hline \multirow[t]{2}{*}{ House Value $€$} & mean & 278,982 & 278,982 & 278,982 & 278,982 & 278,982 & 278,982 & 278,982 & 278,982 & 278,982 & 278,982 & 278,982 & 278,982 \\
\hline & std & 112,278 & 112,278 & 112,278 & 112,278 & 112,278 & 112,278 & 112,278 & 112,278 & 112,278 & 112,278 & 112,278 & 112,278 \\
\hline Derivatives & mean & 0.22 & 0.20 & 0.21 & 0.21 & 0.19 & 0.22 & 0.25 & 0.18 & 0.16 & 0.17 & 0.17 & 0.18 \\
\hline Traded & mean & 0.46 & 0.47 & 0.48 & 0.47 & 0.41 & 0.51 & 0.63 & 0.42 & 0.37 & 0.41 & 0.40 & 0.42 \\
\hline \multirow[t]{2}{*}{ Turnover (Traders) } & mean & 0.55 & 0.46 & 0.42 & 0.60 & 0.46 & 0.62 & 0.99 & 0.73 & 0.61 & 0.80 & 0.67 & 0.78 \\
\hline & std & 1.53 & 1.22 & 1.12 & 1.85 & 1.41 & 1.87 & 3.63 & 1.82 & 1.82 & 2.77 & 2.49 & 2.46 \\
\hline \multirow[t]{2}{*}{ Return } & mean & 0.03 & 0.00 & -0.17 & -0.10 & 0.05 & -0.24 & -0.23 & -0.12 & -0.04 & 0.00 & -0.16 & -0.01 \\
\hline & std & 0.16 & 0.13 & 0.19 & 0.19 & 0.17 & 0.19 & 0.33 & 0.19 & 0.20 & 0.19 & 0.18 & 0.19 \\
\hline \multirow[t]{2}{*}{ Std(Return) } & mean & 0.14 & 0.13 & 0.18 & 0.23 & 0.18 & 0.31 & 0.53 & 0.36 & 0.26 & 0.27 & 0.23 & 0.30 \\
\hline & std & 0.25 & 0.23 & 0.29 & 0.33 & 0.28 & 0.36 & 0.42 & 0.37 & 0.32 & 0.32 & 0.32 & 0.35 \\
\hline
\end{tabular}


Table 2

Descriptive Statistics - continued

\begin{tabular}{|c|c|c|c|c|c|c|c|c|c|c|c|c|c|}
\hline \multirow[b]{2}{*}{ Month } & & \multicolumn{12}{|c|}{ Panel B: Survey Respondents } \\
\hline & & Apr-08 & May-08 & Jun-08 & Jul-08 & Aug-08 & Sep-08 & Oct-08 & Nov-08 & Dec-08 & Jan-09 & Feb-09 & Mar-09 \\
\hline Investors & $\mathrm{N}$ & 787 & 701 & 605 & 557 & 520 & 491 & 650 & 402 & 330 & 312 & 272 & 291 \\
\hline Investors resp. first time & $\mathrm{N}$ & 787 & 68 & 11 & 10 & 2 & 4 & 494 & 0 & 0 & 0 & 0 & 0 \\
\hline Gender (Fraction Female) & mean & 0.07 & 0.08 & 0.08 & 0.08 & 0.08 & 0.08 & 0.09 & 0.08 & 0.08 & 0.08 & 0.09 & 0.09 \\
\hline \multirow[t]{2}{*}{ Age in Years } & mean & 50.55 & 51.22 & 51.50 & 51.83 & 52.79 & 52.60 & 51.50 & 52.31 & 52.65 & 52.64 & 53.83 & 53.25 \\
\hline & std & 13.51 & 13.55 & 13.43 & 13.57 & 12.90 & 13.05 & 13.29 & 13.25 & 12.88 & 12.86 & 12.62 & 12.67 \\
\hline \multirow[t]{2}{*}{ Account Tenure } & mean & 3.93 & 3.98 & 4.09 & 3.98 & 4.11 & 4.08 & 4.26 & 4.35 & 4.34 & 4.45 & 4.53 & 4.38 \\
\hline & std & 2.76 & 2.79 & 2.77 & 2.78 & 2.77 & 2.76 & 2.78 & 2.73 & 2.75 & 2.74 & 2.68 & 2.71 \\
\hline \multirow[t]{2}{*}{ Income $€$} & mean & 20,181 & 20,088 & 20,109 & 19,978 & 20,085 & 20,002 & 20,147 & 19,892 & 19,859 & 20,046 & 20,034 & 20,028 \\
\hline & std & 4,285 & 3,956 & 4,240 & 3,729 & 3,835 & 4,153 & 4,197 & 3,808 & 3,543 & 3,897 & 3,844 & 3,860 \\
\hline \multirow[t]{2}{*}{ Portfolio Value $€$} & mean & 54,446 & 54,264 & 45,411 & 45,509 & 49,557 & 39,707 & 29,490 & 33,660 & 30,169 & 30,693 & 27,444 & 27,229 \\
\hline & std & 143,872 & 144,617 & 128,455 & 128,159 & 124,176 & 105,507 & 100,216 & 118,529 & 66,600 & 66,198 & 53,089 & 55,039 \\
\hline \multirow[t]{2}{*}{ House Value $€$} & mean & 276,690 & 272,969 & 272,038 & 273,559 & 274,221 & 274,736 & 277,543 & 272,429 & 272,020 & 273,443 & 277,193 & 273,037 \\
\hline & std & 110,125 & 102,015 & 109,290 & 101,943 & 101,006 & 110,771 & 112,864 & 104,787 & 98,530 & 99,506 & 108,672 & 100,576 \\
\hline Derivatives & mean & 0.24 & 0.23 & 0.25 & 0.25 & 0.23 & 0.24 & 0.26 & 0.19 & 0.20 & 0.24 & 0.22 & 0.20 \\
\hline Traded & mean & 0.52 & 0.54 & 0.55 & 0.52 & 0.46 & 0.54 & 0.64 & 0.46 & 0.42 & 0.48 & 0.49 & 0.45 \\
\hline \multirow[t]{2}{*}{ Turnover (Traders) } & mean & 0.65 & 0.43 & 0.49 & 0.57 & 0.36 & 0.50 & 1.10 & 0.86 & 0.47 & 0.56 & 0.70 & 1.00 \\
\hline & std & 1.82 & 1.13 & 1.41 & 1.61 & 0.91 & 1.08 & 4.68 & 2.23 & 1.51 & 1.07 & 2.08 & 3.91 \\
\hline \multirow[t]{2}{*}{ Return } & mean & 0.03 & 0.00 & -0.18 & -0.10 & 0.05 & -0.25 & -0.22 & -0.12 & -0.04 & 0.00 & -0.17 & -0.01 \\
\hline & std & 0.17 & 0.12 & 0.18 & 0.18 & 0.20 & 0.18 & 0.34 & 0.19 & 0.16 & 0.20 & 0.20 & 0.21 \\
\hline \multirow[t]{2}{*}{ Std(Return) } & mean & 0.15 & 0.13 & 0.18 & 0.23 & 0.18 & 0.31 & 0.53 & 0.37 & 0.26 & 0.28 & 0.25 & 0.32 \\
\hline & std & 0.29 & 0.22 & 0.29 & 0.34 & 0.30 & 0.38 & 0.43 & 0.39 & 0.32 & 0.31 & 0.38 & 0.43 \\
\hline \multirow[t]{2}{*}{ Return Expectation } & mean & 4.28 & 4.18 & 3.57 & 3.78 & 4.09 & 3.45 & 3.37 & 3.59 & 3.72 & 3.97 & 3.53 & 4.16 \\
\hline & std & 0.94 & 0.92 & 0.96 & 0.97 & 1.00 & 1.06 & 1.04 & 1.10 & 0.99 & 1.09 & 1.17 & 1.06 \\
\hline \multirow[t]{2}{*}{ Risk Perception } & mean & 4.49 & 4.44 & 5.00 & 4.15 & 3.97 & 4.45 & 4.27 & 4.26 & 4.24 & 4.18 & 4.44 & 4.24 \\
\hline & std & 1.63 & 1.58 & 1.93 & 1.13 & 1.15 & 1.17 & 1.31 & 1.28 & 1.24 & 1.22 & 1.32 & 1.20 \\
\hline \multirow[t]{2}{*}{ Risk Tolerance } & mean & 3.91 & 3.93 & 3.58 & 3.77 & 3.85 & 3.56 & 3.67 & 3.70 & 3.79 & 3.74 & 3.73 & 3.86 \\
\hline & std & 1.19 & 1.11 & 1.25 & 1.19 & 1.18 & 1.30 & 1.33 & 1.26 & 1.18 & 1.20 & 1.28 & 1.14 \\
\hline
\end{tabular}

This table presents monthly summary statistics for the brokerage account data. Panel A refers to all investors for whom brokerage records are available. This sample includes investors who participated at least once in the survey during the sample period, and who were not excluded by the sample-selection restrictions defined in Section 2. The monthly summary statistics presented in Panel B refer to the subset of investors who responded to the survey in each respective month. "Investors resp. first time" indicates for each month the number of investors for whom this was their first participation in the survey. All other variables are defined in Table 1. 
Table 3

\section{Survey Questions}

\begin{tabular}{ll}
\hline Survey Variable & \multicolumn{1}{c}{ Answer Categories } \\
\hline Return Expectation (1 = low/pessimistic, 7 = high/optimistic) & \\
$\begin{array}{l}\text { Next month, I expect my investments to do less well than desired. } \\
\begin{array}{l}\text { For the next month, I have a positive feeling about my financial } \\
\text { future. }\end{array}\end{array}$ & 1 (totally agree)-7 (totally disagree) \\
$\begin{array}{l}\text { Next month, my investments will have a worse performance than } \\
\text { those of most other investors. }\end{array}$ & 1 (totally disagree) \\
$\begin{array}{l}\text { Next month, it is unlikely that my investment behavior will lead to } \\
\text { positive returns. }\end{array}$ & 1 (totally disagree) \\
$\begin{array}{l}\text { For the next month, the future of my investment portfolio looks } \\
\text { good.* }\end{array}$ & 1 (totally agree)-7 (totally disagree) \\
\hline
\end{tabular}

Risk Perception ( 1 = low perceived risk, 7 = high perceived risk)

I consider investing to be very risky next month.*

I consider investing to be safe next month.

I consider investing to be dangerous next month.*

I consider investing to have little risk next month.

1 (totally agree) -7 (totally disagree)

1 (totally agree)-7 (totally disagree)

1 (totally agree)-7 (totally disagree)

1 (totally agree) -7 (totally disagree)

Risk Tolerance $(1=$ low risk tolerance, $7=$ high risk tolerance $)$

Next month, I prefer certainty over uncertainty when investing.

Next month, I avoid risks when investing.

Next month, I do not like to take financial risks.

Next month, I do not like to "play it safe" when investing.*

1 (totally agree)-7 (totally disagree)

1 (totally agree) -7 (totally disagree)

1 (totally agree)-7 (totally disagree)

1 (totally agree) -7 (totally disagree)

This table presents the questions used in this study's 12 monthly surveys. A 7-point Likert scale is used to record investors' response to each question. Each survey variable (return expectation, risk perception, risk tolerance) is calculated as the equally weighted average of the respective survey questions. * denotes a reverse-scored question. 
Table 4

Impact of Past Return on Survey Measures

\begin{tabular}{|c|c|c|c|c|c|c|}
\hline \multicolumn{7}{|c|}{ Panel A } \\
\hline \multirow[t]{2}{*}{ Dependent Variable } & \multicolumn{2}{|c|}{$\Delta$ Return Expectation } & \multicolumn{2}{|c|}{$\Delta$ Risk Perception } & \multicolumn{2}{|c|}{$\Delta$ Risk Tolerance } \\
\hline & Coef. & Std. err. & Coef. & Std. err. & Coef. & Std. err. \\
\hline Return & 0.469 & $0.086 * * *$ & -0.223 & $0.133 *$ & 0.186 & $0.110 *$ \\
\hline Gender & 0.053 & 0.039 & -0.027 & 0.055 & -0.015 & 0.041 \\
\hline Age & 0.001 & 0.001 & -0.001 & 0.001 & -0.001 & 0.001 \\
\hline Account Tenure & -0.002 & 0.003 & -0.002 & 0.005 & 0.003 & 0.004 \\
\hline $\ln ($ Income $)$ & 0.014 & 0.088 & 0.095 & 0.161 & -0.116 & 0.105 \\
\hline $\ln$ (Avg. Portfolio Value) & -0.003 & 0.006 & 0.002 & 0.009 & -0.006 & 0.007 \\
\hline $\ln$ (House Value) & 0.016 & 0.045 & -0.040 & 0.074 & -0.004 & 0.051 \\
\hline Derivatives & 0.017 & 0.041 & -0.074 & 0.072 & -0.050 & 0.050 \\
\hline Traded & 0.038 & 0.031 & 0.034 & 0.053 & 0.119 & $0.038 * * *$ \\
\hline Turnover & 0.029 & $0.012 * *$ & -0.041 & $0.017 * *$ & 0.029 & 0.020 \\
\hline Constant & 0.144 & 0.586 & -0.633 & 1.049 & 1.214 & $0.676 *$ \\
\hline Time fixe & \multicolumn{2}{|c|}{ YES } & \multicolumn{2}{|c|}{ YES } & \multicolumn{2}{|c|}{ YES } \\
\hline $\mathrm{N}$ Obs & \multicolumn{2}{|c|}{3,955} & \multicolumn{2}{|c|}{3,955} & \multicolumn{2}{|c|}{3,955} \\
\hline $\mathrm{N}$ Investors & \multicolumn{2}{|c|}{1,045} & \multicolumn{2}{|c|}{1,045} & \multicolumn{2}{|c|}{1,045} \\
\hline $\mathrm{R}^{2}$ & \multicolumn{2}{|c|}{0.165} & \multicolumn{2}{|c|}{0.063} & \multicolumn{2}{|c|}{0.032} \\
\hline \multicolumn{7}{|c|}{ Panel B } \\
\hline Dependent Variable & \multicolumn{2}{|c|}{ Return Expectation } & \multicolumn{2}{|c|}{ Risk Perception } & \multicolumn{2}{|c|}{ Risk Tolerance } \\
\hline & Coef. & Std. err. & Coef. & Std. err. & Coef. & Std. err. \\
\hline Retur & 0.427 & $0.079 * * *$ & -0.214 & $0.107 * *$ & 0.043 & 0.073 \\
\hline Derivatives & 0.076 & 0.053 & -0.094 & 0.090 & 0.029 & 0.057 \\
\hline Traded & 0.114 & $0.031 * * *$ & -0.043 & 0.052 & 0.201 & $0.036 * * *$ \\
\hline Turnover & 0.030 & $0.012 * *$ & -0.009 & 0.014 & 0.022 & $0.013 *$ \\
\hline Constant & 3.595 & $0.069 * * *$ & 4.503 & $0.103 * * *$ & 3.567 & $0.070 * * *$ \\
\hline Individual fixed effects & \multicolumn{2}{|c|}{ YES } & \multicolumn{2}{|c|}{ YES } & \multicolumn{2}{|c|}{ YES } \\
\hline Time fixed effects & \multicolumn{2}{|c|}{ YES } & \multicolumn{2}{|c|}{ YES } & \multicolumn{2}{|c|}{ YES } \\
\hline N Observations & \multicolumn{2}{|c|}{5,918} & \multicolumn{2}{|c|}{5,918} & \multicolumn{2}{|c|}{5,918} \\
\hline $\mathrm{N}$ Investors & & 376 & & ,376 & & 376 \\
\hline Overall $\mathrm{R}^{2}$ & & .103 & & .031 & & .021 \\
\hline
\end{tabular}

Panel A of this table presents the results from regressions of changes in investor return expectation, risk perception, or risk tolerance on past investor returns and a set of control variables. That is, we regress the monthly update of beliefs and preferences on the respective return experience in that month. The columns show results of linear panel models. The number of individual investors included in the regression $(1,045)$ is smaller than the sample available for analysis $(1,376)$ because not all investors responded to the survey for two consecutive months. Panel B presents the results from regressions of levels of investor return expectation, risk perception, or risk tolerance on past investor returns and a set of control variables. That is, we regress the end of the month level of beliefs and preferences on the respective return experience in that month. The columns show results of linear panel models with individual fixed effects. In all models, standard errors are clustered on the investor level. Variables are defined in Table 1. *,**, and *** denote statistical significance at the $10 \%, 5 \%$, and $1 \%$ levels, respectively. 
Table 5

Impact of Past Risk on Survey Measures

\begin{tabular}{|c|c|c|c|c|c|c|}
\hline \multicolumn{7}{|c|}{ Panel A } \\
\hline \multirow[t]{2}{*}{ Dependent Variable } & \multicolumn{2}{|c|}{$\Delta$ Return Expectation } & \multicolumn{2}{|c|}{$\Delta$ Risk Perception } & \multicolumn{2}{|c|}{$\Delta$ Risk Tolerance } \\
\hline & Coef. & Std. err. & Coef. & Std. err. & Coef. & Std. err. \\
\hline Std(Return) & -0.013 & 0.043 & 0.033 & 0.072 & -0.001 & 0.054 \\
\hline Gender & 0.055 & 0.038 & -0.027 & 0.055 & -0.014 & 0.041 \\
\hline Age & 0.000 & 0.001 & -0.001 & 0.001 & -0.001 & 0.001 \\
\hline Account Tenure & -0.002 & 0.003 & -0.003 & 0.005 & 0.003 & 0.004 \\
\hline $\ln ($ Income $)$ & 0.014 & 0.088 & 0.094 & 0.161 & -0.116 & 0.105 \\
\hline $\ln ($ Avg. Portfolio Value) & 0.004 & 0.006 & 0.000 & 0.009 & -0.003 & 0.007 \\
\hline $\ln ($ House Value) & 0.021 & 0.045 & -0.043 & 0.074 & -0.002 & 0.051 \\
\hline Derivatives & -0.017 & 0.041 & -0.062 & 0.075 & -0.064 & 0.051 \\
\hline Traded & 0.031 & 0.031 & 0.036 & 0.053 & 0.116 & $0.038 * * *$ \\
\hline Turnover & 0.017 & 0.012 & -0.037 & $0.016 * *$ & 0.024 & 0.020 \\
\hline Constant & -0.816 & 0.591 & -0.217 & 1.043 & 0.989 & 0.685 \\
\hline Time $f$ & \multicolumn{2}{|c|}{ YES } & \multicolumn{2}{|c|}{ YES } & \multicolumn{2}{|c|}{ YES } \\
\hline N Obs & \multicolumn{2}{|c|}{3,955} & \multicolumn{2}{|c|}{3,955} & \multicolumn{2}{|c|}{3,955} \\
\hline $\mathrm{N}$ Investors & \multicolumn{2}{|c|}{1,045} & \multicolumn{2}{|c|}{1,045} & \multicolumn{2}{|c|}{1,045} \\
\hline $\mathrm{R}^{2}$ & \multicolumn{2}{|c|}{0.158} & \multicolumn{2}{|c|}{0.063} & \multicolumn{2}{|c|}{0.031} \\
\hline \multicolumn{7}{|c|}{ Panel B } \\
\hline Dependent Variable & \multicolumn{2}{|c|}{ Return Expectation } & \multicolumn{2}{|c|}{ Risk Perception } & \multicolumn{2}{|c|}{ Risk Tolerance } \\
\hline & Coef. & Std. err. & Coef. & Std. err. & Coef. & Std. err. \\
\hline Std(Return) & -0.081 & 0.079 & 0.127 & 0.112 & -0.031 & 0.065 \\
\hline Derivatives & 0.068 & 0.053 & -0.090 & 0.090 & 0.028 & 0.057 \\
\hline Traded & 0.110 & $0.032 * * *$ & -0.041 & 0.052 & 0.201 & $0.036 * * *$ \\
\hline Turnover & 0.027 & $0.013 * *$ & -0.009 & 0.014 & 0.022 & $0.013 *$ \\
\hline Constant & 3.542 & $0.070 * * *$ & 4.508 & $0.104 * * *$ & 3.567 & $0.071 * * *$ \\
\hline Individual fixed effects & \multicolumn{2}{|c|}{ YES } & \multicolumn{2}{|c|}{ YES } & \multicolumn{2}{|c|}{ YES } \\
\hline Time fixed effects & \multicolumn{2}{|c|}{ YES } & \multicolumn{2}{|c|}{ YES } & \multicolumn{2}{|c|}{ YES } \\
\hline N Observations & \multicolumn{2}{|c|}{5,918} & \multicolumn{2}{|c|}{5,918} & \multicolumn{2}{|c|}{5,918} \\
\hline $\mathrm{N}$ Investors & & ,376 & & ,376 & & 1,376 \\
\hline Overall $\mathrm{R}^{2}$ & & .098 & & .031 & & 0.021 \\
\hline
\end{tabular}

Panel A of this table presents the results from regressions of changes in investor return expectation, risk perception, or risk tolerance on the realized risk of investor returns (standard deviation of return) and a set of control variables. That is, we regress the monthly update of beliefs and preferences on the respective risk experience in that month. The columns show results of linear panel models. The number of individual investors included in the regression $(1,045)$ is smaller than the sample available for analysis $(1,376)$ because not all investors responded to the survey for two consecutive months. Panel B presents the results from regressions of levels of investor return expectation, risk perception, or risk tolerance on the realized risk of investor returns (standard deviation of return) and a set of control variables. That is, we regress the end of the month level of beliefs and preferences on the respective risk experience in that month. The columns show results of linear panel models with individual fixed effects. In all models, standard errors are clustered on the investor level. Variables are defined in Table $1 .{ }^{*}, * *$, and *** denote statistical significance at the $10 \%, 5 \%$, and $1 \%$ levels, respectively. 
Table 6

Impact of Past Return and Risk on Survey Measures

\begin{tabular}{|c|c|c|c|c|c|c|}
\hline \multirow{2}{*}{ Dependent Variable } & \multicolumn{2}{|c|}{ Return Expectation } & \multicolumn{2}{|c|}{ Risk Perception } & \multicolumn{2}{|c|}{ Risk Tolerance } \\
\hline & Coef. & Std. err. & Coef. & Std. err. & Coef. & Std. err. \\
\hline Return & 0.433 & $0.077 * * *$ & -0.188 & $0.110 *$ & 0.036 & 0.077 \\
\hline Std(Return) & 0.018 & 0.076 & 0.084 & 0.115 & -0.023 & 0.069 \\
\hline Derivatives & 0.076 & 0.053 & -0.094 & 0.090 & 0.029 & 0.057 \\
\hline Traded & 0.114 & $0.031 * * *$ & -0.043 & 0.052 & 0.201 & $0.036 * * *$ \\
\hline Turnover & 0.029 & $0.012 * *$ & -0.010 & 0.014 & 0.022 & $0.013 *$ \\
\hline Constant & 3.592 & $0.070 * * *$ & 4.487 & $0.105 * * *$ & 3.571 & $0.072 * * *$ \\
\hline Individual fixed effects & \multicolumn{2}{|c|}{ YES } & \multicolumn{2}{|c|}{ YES } & \multicolumn{2}{|c|}{ YES } \\
\hline Time fixed effects & \multicolumn{2}{|c|}{ YES } & \multicolumn{2}{|c|}{ YES } & \multicolumn{2}{|c|}{ YES } \\
\hline N Observations & \multicolumn{2}{|c|}{5,918} & \multicolumn{2}{|c|}{5,918} & \multicolumn{2}{|c|}{5,918} \\
\hline $\mathrm{N}$ Investors & \multicolumn{2}{|c|}{1,376} & \multicolumn{2}{|c|}{1,376} & \multicolumn{2}{|c|}{1,376} \\
\hline Overall $\mathrm{R}^{2}$ & \multicolumn{2}{|c|}{0.104} & \multicolumn{2}{|c|}{0.032} & \multicolumn{2}{|c|}{0.021} \\
\hline
\end{tabular}

This table presents the results from regressions of levels of investor return expectation, risk perception, or risk tolerance on past investor returns, realized risk of investor returns (standard deviation of return), and a set of control variables. That is, we regress the end of the month level of beliefs and preferences on the respective return and risk experience in that month. The columns show results of linear panel models with individual fixed effects. Standard errors in all models are clustered on the investor level. Variables are defined in Table 1. *, **, and *** denote statistical significance at the $10 \%, 5 \%$, and $1 \%$ levels, respectively. 
Table 7

\section{Impact of Past Return and Risk on Changes in Survey} Measures-Alternative Return and Risk Measures

\begin{tabular}{|c|c|c|c|c|c|c|}
\hline \multicolumn{7}{|c|}{ Panel A: Impact of Past Performance } \\
\hline \multirow{2}{*}{ Dependent Variable } & \multicolumn{2}{|c|}{$\Delta$ Return Expectation } & \multicolumn{2}{|c|}{$\Delta$ Risk Perception } & \multicolumn{2}{|c|}{$\Delta$ Risk Tolerance } \\
\hline & Coef. & Std. err. & Coef. & Std. err. & Coef. & Std. err. \\
\hline Alpha & 0.410 & $0.086 * * *$ & -0.323 & $0.112 * * *$ & 0.234 & $0.101 * *$ \\
\hline Sharpe Ratio & 0.205 & $0.028 * * *$ & -0.062 & 0.047 & 0.029 & 0.037 \\
\hline \multicolumn{7}{|c|}{ Panel B: Impact of Realized Risk } \\
\hline \multirow{2}{*}{ Dependent Variable } & \multicolumn{2}{|c|}{$\Delta$ Return Expectation } & \multicolumn{2}{|c|}{$\Delta$ Risk Perception } & \multicolumn{2}{|c|}{$\Delta$ Risk Tolerance } \\
\hline & Coef. & Std. err. & Coef. & Std. err. & Coef. & Std. err. \\
\hline Beta & -0.002 & 0.016 & -0.030 & 0.029 & -0.010 & 0.020 \\
\hline Idiosyncratic Volatility & 0.009 & 0.059 & 0.059 & 0.094 & 0.004 & 0.073 \\
\hline Semi-Standard Deviation (Index Return) & -0.039 & 0.039 & 0.057 & 0.069 & -0.072 & 0.061 \\
\hline Semi-Standard Deviation (Zero Return) & -0.045 & 0.042 & 0.041 & 0.068 & -0.059 & 0.056 \\
\hline Percent Returns below Target (Index Return) & -0.683 & $0.142 * * *$ & 0.264 & 0.249 & -0.034 & 0.188 \\
\hline Percent Returns below Target (Zero Return) & -0.587 & $0.168 * * *$ & 0.066 & 0.279 & 0.196 & 0.218 \\
\hline Average of 4 Worst Returns & 0.135 & $0.081 *$ & 0.037 & 0.152 & 0.029 & 0.107 \\
\hline
\end{tabular}

This table presents the results from regressions of changes in investor return expectation, risk perception, or risk tolerance on alternative past investor return measures (Alpha, Sharpe ratio; Panel A), and alternative realized risk measures (Beta, idiosyncratic volatility, semi-standard deviation, percent returns below target, average of four worst returns; Panel B) and a set of control variables. That is, we regress the monthly update of beliefs and preferences on the respective return and risk experiences in that month. The columns show results of the same panel models previously used in Table 4 (Panel A), with alternative measures for past returns and risk. Each line reported refers to an alternative model specification (separate regression). All returns and risk variables are scaled to refer to monthly terms. Variables are defined in Table 1 . Standard errors are clustered on the investor level. *, **, and *** denote statistical significance at the $10 \%, 5 \%$, and $1 \%$ levels, respectively. 
Table 8

Impact of Past Return on Changes in Survey Measures-Interactions with Investor Characteristics

\begin{tabular}{lrrrrrr}
\hline Dependent Variable & \multicolumn{2}{c}{$\Delta$ Return Expectation } & \multicolumn{2}{c}{$\Delta$ Risk Perception } & \multicolumn{2}{c}{$\Delta$ Risk Tolerance } \\
\hline & \multicolumn{2}{c}{ Coef. } & Std. err. & \multicolumn{1}{c}{ Coef. } & Std. err. & \multicolumn{2}{c}{ Coef. } & Std. err. \\
Return & 0.413 & $0.093^{* * *}$ & -0.190 & 0.146 & 0.140 & 0.117 \\
Age $>75 \% *$ Return & 0.258 & $0.154^{*}$ & -0.142 & 0.241 & 0.202 & 0.215 \\
\hline Return & 0.435 & $0.088^{* * *}$ & -0.159 & 0.143 & 0.351 & $0.111^{* * *}$ \\
Account Tenure $>75 \% *$ Return & 0.117 & 0.174 & -0.214 & 0.245 & -0.576 & $0.213 * * *$ \\
\hline Return & 0.406 & $0.095 * * *$ & -0.225 & 0.153 & 0.316 & $0.126^{* *}$ \\
Income $>50 \% *$ Return & 0.136 & 0.147 & 0.006 & 0.222 & -0.278 & $0.162 *$ \\
\hline
\end{tabular}

This table presents the results from regressions of changes in investor return expectation, risk perception, or risk tolerance on past investor returns and a set of control variables. That is, we regress the monthly update of beliefs and preferences on the respective return experience in that month. The columns show results of the same panel models previously used in Table 4 (Panel A), while also including alternative interaction terms. In each regression model, only one interaction term (and the main effect of the respective indicator variables) is included at the same time. That is, each two-variable block reported refers to an alternative model specification (separate regression). Reported are the main effect of the respective return variable and the interaction effect. Interaction variables with percentages refer to the quartiles in the distribution of the respective variable in the investor sample. Other variables are defined in Table 1. Standard errors are clustered on the investor level. *,**, and *** denote statistical significance at the $10 \%, 5 \%$, and $1 \%$ levels, respectively. 
Table 9

Impact of Past Risk on Changes in Survey Measures-Interactions with Investor Characteristics

\begin{tabular}{|c|c|c|c|c|c|c|}
\hline \multirow{2}{*}{ Dependent Variable } & \multicolumn{2}{|c|}{$\Delta$ Return Expectation } & \multicolumn{2}{|c|}{$\Delta$ Risk Perception } & \multicolumn{2}{|c|}{$\Delta$ Risk Tolerance } \\
\hline & Coef. & Std. err. & Coef. & Std. err. & Coef. & Std. err. \\
\hline Std(Return) & -0.005 & 0.044 & 0.023 & 0.078 & 0.022 & 0.055 \\
\hline Age $>75 \% * \operatorname{Std}($ Return $)$ & -0.039 & 0.095 & 0.039 & 0.136 & -0.105 & 0.113 \\
\hline Std(Return) & -0.007 & 0.052 & -0.030 & 0.082 & -0.034 & 0.062 \\
\hline Account Tenure $>75 \% * \operatorname{Std}($ Return $)$ & -0.015 & 0.071 & 0.159 & $0.096 *$ & 0.087 & 0.088 \\
\hline Std(Return) & -0.035 & 0.054 & 0.057 & 0.098 & -0.024 & 0.062 \\
\hline Income $>50 \% * \operatorname{Std}($ Return $)$ & 0.044 & 0.070 & -0.049 & 0.112 & 0.045 & 0.083 \\
\hline
\end{tabular}

This table presents the results from regressions of changes in investor return expectation, risk perception, or risk tolerance on the realized risk of investor returns (standard deviation of returns) and a set of control variables. That is, we regress the monthly update of beliefs and preferences on the respective risk experience in that month. The columns show results of the same panel models previously used in Table 5 (Panel A), while also including alternative interaction terms (and the main effect of the respective indicator variables). In each regression model, only one interaction term is included at the same time. That is, each two-variable block reported refers to an alternative model specification (separate regression). Reported are the main effect of the respective return risk variable and the interaction effect. Interaction variables with percentages refer to the quartiles in the distribution of the respective variable in the investor sample. Other variables are defined in Table 1. Standard errors are clustered on the investor level. *,**, and $* * *$ denote statistical significance at the $10 \%, 5 \%$, and $1 \%$ levels, respectively. 